Philosophie in Rom - Römische Philosophie? 


\section{Beiträge zur Altertumskunde}

Herausgegeben von

Susanne Daub, Michael Erler, Dorothee Gall,

Ludwig Koenen und Clemens Zintzen

\section{Band 358}




\section{Philosophie in Rom - Römische Philosophie?}

Kultur-, literatur- und philosophiegeschichtliche Perspektiven

Herausgegeben von

Gernot Michael Müller und Fosca Mariani Zini

\section{DE GRUYTER}


ISBN 978-3-11-048872-2

e-ISBN (PDF) 978-3-11-049310-8

e-ISBN (EPUB) 978-3-11-049142-5

ISSN 1616-0452

\section{Library of Congress Cataloging-in-Publication Data}

A CIP catalog record for this book has been applied for at the Library of Congress.

\section{Bibliografische Information der Deutschen Nationalbibliothek}

Die Deutsche Nationalbibliothek verzeichnet diese Publikation in der Deutschen Nationalbibliografie; detaillierte bibliografische Daten sind im Internet über http://dnb.dnb.de abrufbar.

(C) 2018 Walter de Gruyter GmbH, Berlin/Boston

Druck und Bindung: Hubert und Co. GmbH \& Co. KG, Göttingen

@ Gedruckt auf säurefreiem Papier

Printed in Germany

www.degruyter.com 


\section{Inhaltsverzeichnis}

Gernot Michael Müller und Fosca Mariani Zini

Einleitung -1

I. Kultur- und mentalitätsgeschichtliche Grundlagen der Philosophie in Rom

Jean-Christophe Jolivet

Philosophes et philologues hellénistiques, ambassadeurs et héros culturels à

Rome: le cas de Cratès de Mallos — 43

Jochen Sauer

Römische Exempla-Ethik und Konsenskultur?

Philosophie und mos maiorum bei Cicero und Seneca - 67

II. Gesellschaftliche und literarische Rollenkonzepte für eine Selbstdefinition des Philosophen in Rom

Therese Fuhrer

Philosophische Literatur in Rom als Medium der Definition sozialer

Rollen - 99

Gernot Michael Müller

Philosophie im Plauderton.

Zum philosophischen Gehalt der Horazischen Episteln — 115

III. Griechische Philosophen und ihr römisches Umfeld im 1. Jh. v. Chr.

Georgia Tsouni

The 'Academy' in Rome: Antiochus and his vetus Academia - 139

Daniel Delattre

Philodème et le portrait moral dans le livre $X$ des Vices

([L’Arrogance], PHerc. 1008) - 151 


\section{Zum Verhältnis von Philosophie und Rhetorik in philosophischer Literatur und rhetorischer Theorie}

Michael Erler

Beweishäufung bei Lukrez. Zum Verhältnis von Philosophie und Rhetorik in philosophischer Literatur 175

Thomas Schirren

Wieviel Philosophie braucht der Redner? Zur Bedeutung der Philosophie in der Institutio oratoria des Quintilian 189

\section{Ciceros politische Philosophie und die Krise der römischen Republik}

Jonathan G. F. Powell

Philosophising about Rome. Cicero's De re publica and De legibus -249

Catherine Steel

Re publica nihil desperatius: salvaging the state in Cicero's pre-civil war philosophical works -269

\section{Skeptizismus und Erkenntnistheorie bei Cicero und Augustin}

Carlos Lévy

De la rhétorique à la philosophie:

le rôle de la temeritas dans la pensée et l'œuvre de Cicéron — 285

Tobias Reinhardt

Cicero and Augustine on Grasping the Truth -305 
VII. Argumentationstechniken für eine Philosophie als Therapie: Cicero und Seneca im Vergleich

Fosca Mariani Zini

Argumentation als Trost.

Bemerkungen über Ciceros Tusculanen, Buch I -327

Claudia Wiener

Stoa ohne stoische Terminologie? Senecas Vermittlungsstrategien - 349

VIII. Elemente einer stoischen Anthropologie für die römische Gesellschaft des 1. Jh.s n. Chr. im Guvre Senecas

Jula Wildberger

Amicitia and Eros: Seneca's Adaptation of a Stoic Concept of Friendship for Roman Men in Progress - 387

Jörn Müller

Senecas Phaedra: Stoisches Porträt einer akratischen Persönlichkeit - 427

IX. Philosophie und Naturkunde im 1. Jh. n. Chr.

Bardo Maria Gauly

Plinius' Zoologie und die römische Naturgeschichte -469

\section{Zu Rezeption und Überlieferung römischer Philosophie am Ausgang der Spätantike}

Clara Auvray-Assayas

Lectures néoplatoniciennes de Cicéron: le témoignage du manuscrit Reg. Lat. 1762 de la Bibliothèque Vaticane -491

\section{Anhang}

Index -501

Index locorum $\longrightarrow 507$ 
Bereitgestellt von | De Gruyter / TCS

Angemeldet

Heruntergeladen am | 18.12.17 11:47 


\title{
Cicero and Augustine on Grasping the Truth*
}

\author{
Tobias Reinhardt
}

Sometimes the history of philosophy can be illuminated by studying the development of philosophical terminology. The particular way in which Cicero renders in Latin the Hellenistic debate about the cataleptic impression influences the way in which Augustine talks about, and possibly conceives of, certain epistemological problems and in which he formulates new views - views which were to remain seminal long after the end of antiquity. ${ }^{1}$ The purpose of this study is to describe this process with greater precision and accuracy than earlier attempts have done.

To anticipate, Stoics speak of grasping objects by means of cataleptic impressions which reveal themselves and their cause. Percipere uisum can for Cicero mean 'grasping an object by means of a cataleptic impression', i.e. grasping the object and the impression it gives rise to, but since uisum can also denote the impression alone and since there are situations in which Cicero needs to talk about mental items only, percipere uisum can also mean the grasping of an impression only. This terminological shift of Cicero's allows Augustine to restrict what we can 'grasp', i.e. have secure knowledge of, to truths which are unrelated to the external world and are not representations of objects or statesof-affairs in it.

The Stoics believe we can grasp objects in the world around us by means of self-warranting cataleptic impressions. As they put it, using cognates of the verb $\kappa \alpha \tau \alpha \lambda \alpha \mu \beta \dot{\alpha} \nu \varepsilon เ v,{ }^{2}$ we experience impressions which are capable of grasping or of

\footnotetext{
* Translations are my own unless otherwise indicated. I am grateful to J. N. Adams and M. Thakkar for advice, to G. M. Müller and F. Mariani Zini for inviting me to participate in the conference at Hirschberg, and to the other participants for their questions and comments.

1 Noted by, e.g. Charles Brittain: Cicero - On Academic Scepticism, Indianapolis/Cambridge 2006, xliii-iii.

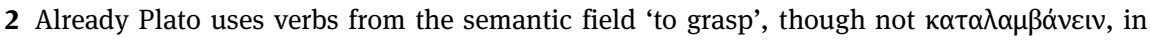
connection with the mental grasp of something; see Anthony Arthur Long: Zeno's Epistemology and Plato's Theaetetus, in: Theodore Scaltsas; Andrew S. Mason (eds.): The Philosophy of

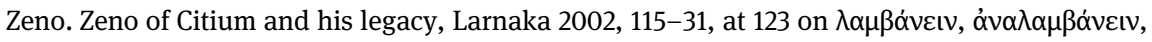

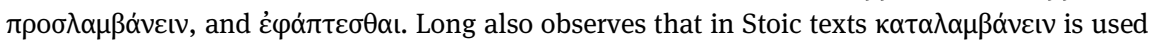
of true items only, while the terms used by Plato can be applied to truths and falsehoods alike.
} 


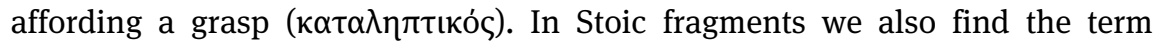
$\kappa \alpha \tau \alpha \lambda \eta \pi \tau$ ó, 'capable of being grasped', i.e. morphologically the passive counterpart of the active к $\alpha \tau \alpha \lambda \eta \pi \tau$ เó, , but while the latter is a frequently attested attribute of impressions, the former is a rarely attested attribute of objects in the world, not because these are not grasped by means of cataleptic impressions (they are), but because objects in the world are not problematic for Stoics - to call them capable of being grasped would, outside of dialectical debate, be a

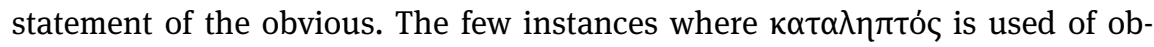
jects in Stoic texts confirm this: e.g. someone is said to be $\kappa \alpha \tau \alpha \lambda \eta \pi \tau$ ó i.e. it is not someone's graspability qua object which is at issue, but whether one can apprehend through perception if someone is a sage. ${ }^{3}$ Cataleptic impressions by themselves do not lead to beliefs. For beliefs to ensue from them, the mind has to assent to them. Once they have been assented to, they are called a 'grasp'

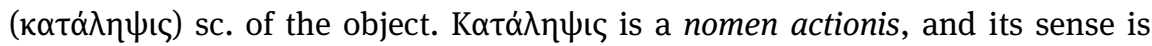
active. At the same time, because $\kappa \alpha \tau \alpha \lambda \dot{\eta} \psi \varepsilon \iota \varsigma$ are impressions which have been assented to, they are mental items; this is not an unusual shift in meaning for nouns of this formation $\left(\delta\right.$ ó $\sigma \mathrm{s}=$ the giving $>$ gift, payment; ${ }^{4} \mathrm{cf}$. natatio $=$ the swim > swimming pool). The verb $\kappa \alpha \tau \alpha \lambda \alpha \mu \beta \alpha \dot{v} \varepsilon \iota v$, unless it is modally qualified,

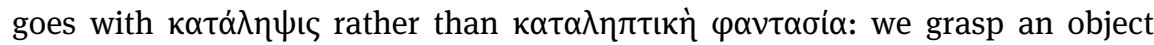
when we have a cataleptic impression of it and assent to it, not just by having a $\kappa \alpha \tau \alpha \lambda \eta \pi \tau \iota \kappa \dot{~} \varphi \alpha \nu \tau \alpha \sigma i \alpha$. A formulation which is not present in the Greek record on the Stoics is that we grasp impressions by assenting to them, but I will later discuss material which suggests that a later Stoic, or a Stoicising Academic like Antiochus, might have used such an expression.

The cataleptic impression is defined by Zeno in the following way: ${ }^{5}$

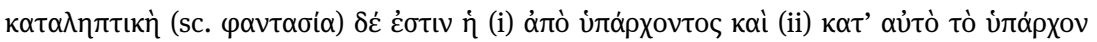

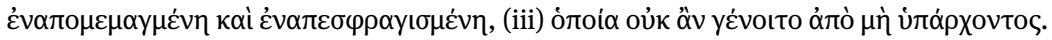

A cataleptic impression is one which is from what obtains, imprinted and stamped on in exact accordance with what obtains, which could not come about from what does not obtain.

The definition consists of three clauses. The first two of these pick out enclosing subsets within the class of impressions (which initially divides into true and false impressions), while the third clause is capable of two interpretations, on

3 Aet. plac. IV,9,17 = SVF 1,204.

4 See, e.g., Émile Benveniste: Noms d'agent et noms d'action en indo-européen, Paris 1948, 76.

5 S. Emp. adv. math. 7,248 = SVF 1,59, p. 18,7-9 = frg. 247 Hülser. 
the first (stronger) of which it represents a further restriction, while it only represents a clarification but no substantial alteration on the second. ${ }^{6}$ On the interpretation of tò úrópxov in (i) hangs an issue on which Sextus and Cicero disagree and which will become important below: ${ }^{7}$ Sextus, in his comments on the definition in Aduersus Mathematicos 7,249, takes the term to mean 'an actually existing object', which entails that the first clause stipulates that the cataleptic impression be an impression as opposed to an empty figment of the mind which does not have its origin in a real object ( $\varphi \alpha \dot{v} \tau \alpha \sigma \mu \alpha)$; this leaves veridicality to be established by the second clause. By contrast, Cicero, in Lucullus 42 and 112, takes tò úrópxov to mean 'that which obtains' or 'that which is the case' (uerum), which shifts veridicality into the first clause. ${ }^{8}$ The main reason for thinking that this is correct is that the alternative reading, which would leave it to the second clause to establish veridicality, would have the third clause reiterate that the kind of impression at issue would have to meet the condition specified in the first clause, which would be of no use. ${ }^{9}$ Cicero tells us that the original Zenonian definition of the cataleptic impression consisted only of the first two clauses, and that the third one was added after Arcesilaus urged that there might be an impression just like one which meets the criteria specified by the definition but which is false. ${ }^{10}$ The addition of this clause, as well as the objection which motivated it, gave rise to a series of anti-Stoic arguments intended to show that, for any true impression we have, there could be a false one just like it. These so-called arguments from $\alpha \dot{\alpha} \alpha \rho \alpha \lambda \lambda \alpha \xi i \alpha$ or non-distinctness made it incumbent on the Stoics to show that, at least under certain conditions, our impressions did not just match an object exactly but were also identifiable for

6 See, e.g., Michael Frede: Stoics and Skeptics on Clear and Distinct Impressions, in: Michael Frede (ed.): Essays in Ancient Philosophy, Oxford 1987, 151-76, at 165; Gisela Striker: Academics fighting Academics, in: Brad Inwood; Jaap Mansfeld (eds.): Assent and Argument - Studies in Cicero's Academic Books. Proceedings of the $7^{\text {th }}$ Symposium Hellenisticum (Utrecht, August 21-25, 1995), Leiden 1997 (Philosophia antiqua 76), 257-276, at 265-266.

7 See Frede: Stoics and Skeptics (as in n. 6), 164-165; David Sedley: Zeno's Definition of the phantasia kataleptike, in: Scaltsas; Mason (eds.): The Philosophy of Zeno (as in n. 2), 133-154.

8 The meaning of úrópxeıv is captured by Ada Bronowski: The Stoic Theory of Lekta, D.Phil.

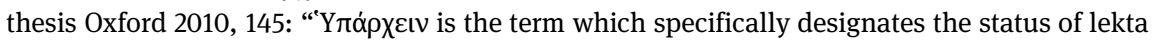

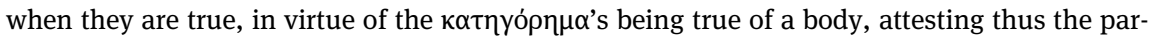
ticular ontological status facts have in Stoic ontology"; see also 148-50 on the occurrence of vंтópxov in the definition. Cf. Pierre Hadot: Vorgeschichte des Begriffes ,Existenz bei den Stoikern, in: Archiv für Begriffsgeschichte 13 (1969), 115-127, at 126.

9 See Sedley: Zeno's Definition (as in n. 7), 138-139.

10 Cic. Luc. 77. 
us as caused by the object in question. ${ }^{11}$ Moreover, impressions are not mental images of the world which the perceiver can look at. Rather, they amount to an openness to the world, 'indicating in themselves also their object' to the perceiver; consider the following fragment: ${ }^{12}$

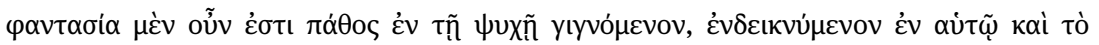

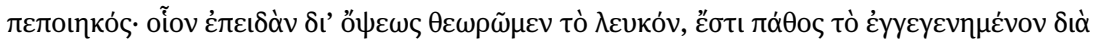

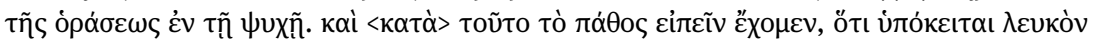

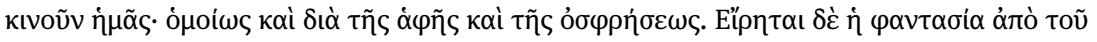

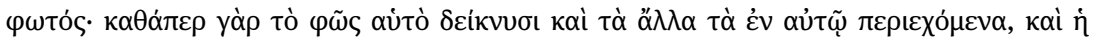

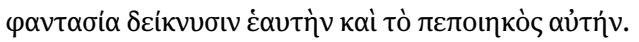

An impression is an affection occurring in the soul, which indicates in itself also its cause. Thus, when through sight we observe something white, the affection is what is engendered in the soul through vision; and it is this affection which enables us to say that there is a white object which activates us. Likewise when we perceive through touch and smell. The word 'impression' is derived from 'light'; just as light reveals itself and whatever else it includes in its range, so impression indicates itself and its cause (Transl. Long \& Sedley, modified).

When Cicero renders the debate between Stoics and Academics into Latin, he does this, as I am arguing elsewhere, ${ }^{13}$ on the basis of an antecedent analysis of how the various philosophical positions about perceptual experiences map onto attitudes towards perception which are encoded into pre-philosophical Latin usage. A consequence of this is that passages which introduce Cicero's 'translation' for a technical Greek term would be misread if they were taken to mean that Cicero intended the two terms to correspond to each other in an uncomplicated way. Indeed, the Latin terms, which are frequently neologisms, are sometimes silently dropped immediately after their introduction in favour of different expressions.

Consider the following two passages:

11 On such arguments see Striker: Academics (as in n. 6), at 266-272; Casey Perin: Academic Arguments for the Indiscernibility Thesis, in: Pacific Philosophical Quarterly 86 (2005), 493517. Cf. Cic. Luc. 40,58 for the distinction between a difference between impressions qua mental imprint or alteration and a difference which can be recognised by the perceiver.

12 Aet. plac. IV,12 = SVF 2,54 = LS 39B.

13 Tobias Reinhardt: To See and To Be Seen: on Vision and Perception in Lucretius and Cicero, in: Katharina Volk; Gareth D. Williams (eds.): Roman Reflections. Essays in Latin Philosophy, Oxford 2016, 63-90. 


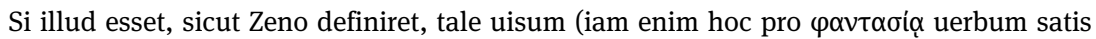
hesterno sermone triuimus). ${ }^{14}$

If the latter was as Zeno defined it - i.e., as an impression (by now we are sufficiently used to this word for phantasia from yesterday's discussion) (Transl. Brittain).

Alterum est quod negatis actionem ullius rei posse in eo esse qui nullam rem adsensu suo conprobet. Primum enim uideri oportet, in quo sit etiam adsensus (dicunt enim Stoici sensus ipsos adsensus esse, quos quoniam adpetitio consequatur actionem sequi) - tolli autem omnia si uisa tollantur. ${ }^{15}$

The second is your denial of the possibility of action of any kind by someone who fails to approve anything with assent. One must first have an impression, which itself involves assent. You see, the Stoics claim that our perceptions are themselves assents and that action follows them (because impulse results from them); hence, everything goes if <apprehensible> impressions go (Transl. Brittain; his emphasis).

The first passage informs us that uisum is Cicero's translation for the term

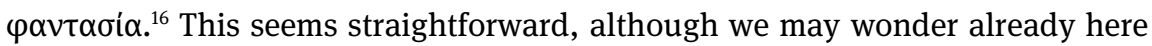
if uisum could not designate either the impression or the object which causes it, or indeed both. In the second passage the sense requires uisa to mean not just 'true impressions' but 'cataleptic impressions' (sc. a sub-class of true impressions). ${ }^{17}$ This raises a number of questions, like whether it should surprise us that this shift in meaning is not more clearly marked, but also how exactly it is achieved given existing uses of uideri. In response to the latter, we can observe that in cases of prototypical (sc. veridical) seeing two claims are made at the same time: that there is an object within the ken of the perceiver on which she is focusing, and that the perceiver has a visual experience of this object. Put differently, in instances of veridical seeing objects in the world present themselves in the experience of the perceiver. Correspondingly, the term uisum, if construed with reference to prototypical uidere, refers to object perceived and visual experience had of it at the same time. Putting it like that may sound as if uisum in this sense is ambiguous in that it has two quite distinct referents, an object in

14 Cic. Luc. 18.

15 Cic. Luc. 108.

16 Visum was used before Cicero in the sense of 'appearance'; see OLD s.v. 1 and nn. 18 and 23 below.

17 See Cic. ac. 41: quod autem erat sensu comprensum id ipsum sensum appellabat, et si ita erat comprensum ut conuelli ratione non posset scientiam; Aet. plac. IV,8,12 and IV,9,4 = SVF 2,72 and 2,78. 
the world and its mental representation, ${ }^{18}$ but in fact the suggestion is that uisa in the sense at issue are so called because external objects present themselves in the experience of the perceiver. Visum in the sense of 'cataleptic impression' reflects a naive realist view of perception.

My contention is that the phrase percipere uisum, whereby uisum has the sense of 'cataleptic impression' in the way just described, has to be considered as the fundamental reference point in interpreting Cicero's account of the debate between Stoics and Academics. Percipere uisum so understood means to grasp the object and the impression it causes at the same time, by assenting to

18 Visum can have two distinct referents at the same time, but whether it should be so construed in a given case depends, or so I think, on complex factors, including the meaning of any verb whose grammatical object uisum is and the artistic intent (to use a term from the museum of literary criticism) of the author. This may be illustrated by two occurrences of uisum outside of a philosophical context. A case where the assumption of two referents feels necessary is Propertius 2,6,27-30 (P. is speaking of obscene wall paintings): quae manus obscenas depinxit prima tabellas / et posuit casta turpia uisa domo / illa puellarum ingenuos corrupit ocellos / nequitiaeque suae noluit esse rudes ("It was the artist who first painted lewd panels and set up indecent pictures in a virtuous house, who corrupted the innocent eyes of girls, refusing to leave them ignorant of his own depravity”, transl. Goold). On first approach, uisa are the paintings qua object seen; this is suggested by posuit (casta [...] domo). And yet, Paolo Fedeli: Properzio: Elegie, Libro II. Introduzione, testo e commento, Cambridge 2005 (Area 45), at 212 comments on the passage: "nel v. 28 visa non perde qui del tutto il senso proprio di 'apparizioni', 'visioni'”, by which, I take it, he means that the paintings are not just tableaux on the wall: an indecent image must do more than be on display to have its corrupting force: it must register with the observer (this is arguably stated in lines 29-30). Here it would seem that both perspectives are required and are to be taken simultaneously. Contrast Dido's ill-omened sacrifice (Verg. Aen. 4,450-6): tum uero infelix fatis exterrita Dido / mortem orat; taedet caeli conuexa tueri. / quo magis inceptum peragat lucemque relinquat, / uidit, turicremis cum dona imponeret aris, / (horrendum dictu) latices nigrescere sacros / fusaque in obscenum se uertere uina cruorem; / hoc uisum nulli, non ipsi effata sorori ("Then it was that unhappy Dido prayed for her death. She had seen her destiny and was afraid. She could bear no longer to look up to the bowl of heaven, and her resolve to leave the light was strengthened when she was laying offerings on the incense-breathing altars and saw to her horror the consecrated milk go black and the wine, as she poured it, turn to filthy gore. She told nobody what she had seen, not even her sister”, transl. West, modified). Here uidit initially suggests that we are dealing with an instance of prototypical seeing, while uisum raises at least the question whether Dido's imagination has in fact played a trick on her and she is hallucinating (in which case uidit would be seeing qua perceptual experience only); cf. Arthur Stanley Pease: Publi Vergili Maronis Aeneidos Liber Quartus, Cambridge, Ma. 1935, on 4,456: "Virgil may think of this uisum as an hallucination on the part of Dido." Here it is either one or the other, for the text is delicately balanced on the edge between the two possibilities, and its effect depends on the reader sharing Dido's uncertainty about what she has seen. 
it. ${ }^{19}$ This formulation is explicit on one important point which the corresponding Greek formulations do not convey: that in assenting to a cataleptic impression we acquire a secure hold of not just the object, but also of the impression it causes, in such a way that it is excluded that what we have actually assented to is an impression just like the one we took ourselves to assent to. ${ }^{20}$ The phrase percipere uisum thus construed implies that the Stoic position is supposed to be immune to the charge of $\alpha \pi \alpha \rho \alpha \lambda \lambda \alpha \xi i \alpha .^{21}$

However, while percipere uisum in its archetypal sense is an elegant way of referring to the grasping of mind-independent facts through perception, Cicero may find himself in situations where he needs to talk about impressions or even cataleptic impressions qua mental items only, e.g. when he reports Zeno's definition (which is of a mental item, not of objects and the impressions caused by them at the same time), or when his focus is on our secure grasp of an impression as opposed to one just like it. In this case he may use expressions like percipere uisum and mean the grasping of a mental item only, without thereby implying or being committed to the view that such impressions do not represent objects in the world or are, in the case of cataleptic impressions, veridical and self-warranting representations of them. In general, ancient sceptics, Academics or Pyrrhonists, have been appropriately characterised as property sceptics, not external world sceptics: they do not take the step which later philosophers will take, of disputing that there is an external world beyond our consciousness, and instead query whether it is appropriately and accurately presented in our experience. ${ }^{22}$ A passage which illustrates this is the following, in which the scep-

19 See also section 2. of Reinhardt: To See and To Be Seen (as in n. 13).

20 However, as Brittain: Cicero (as in n. 1), at xliii n. 84 notes, the later Stoic Hierocles (c. 2 AD) states that the apprehension ( $\left.\dot{\alpha} v \tau^{\prime} \lambda \eta \psi \iota \varsigma\right)$ of something white has to be coordinated with a perception ( $\alpha$ lı $\sigma \theta \eta \sigma \varsigma)$ of oneself being whitened, which suggests that he took two cataleptic impressions to be involved in one's conscious perception of something white (Elements of Ethics VI,1-6); cf. Ilaria Ramelli; David Konstan: Hierocles the Stoic: Elements of Ethics, Fragments, and Excerpts, Atlanta 2009 (Writings from the Greco-Roman world 28), at 16 and 53.

21 Whether the Stoic position was originally meant to be insulated against the kind of objec-

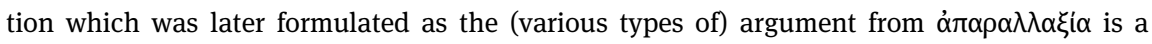
separate question. Within the Academica, Cicero does not present the doctrine as one which has, in this respect, evolved over time. Julia Annas: Stoic Epistemology, in: Stephen Everson (ed.): Epistemology, Companions to Ancient Thought 1, Cambridge 1990, 184-203, argues that the Stoic position was originally indeterminate regarding an awareness requirement being placed on one's self-warrantingly true perceptions and was forced into an externalist position one which does without an awareness requirement - by the considerations from $\alpha \dot{\pi} \alpha \rho \alpha \lambda \lambda \alpha \xi i \alpha$. 22 See Myles Burnyeat: Idealism and Greek Philosophy: What Descartes Saw and Berkeley Missed, in: Philosophical Review 91 (1982), 3-40; Michael Frede: A Medieval Source of Modern 
tic refuses to ascribe a particular colour to the sea, but has no hesitation to refer to the sea with a deictic pronoun (illud): ${ }^{23}$

Mare illud, quod nunc Fauonio nascente purpureum uidetur, idem huic nostro uidebitur, nec tamen adsentietur, quia nobismet ipsis modo caeruleum uidebatur mane rauum [...].

This stretch of sea, which now looks dark as the west wind gets up, will look the same to our wise person. Yet he won't assent <to this impression>, because it looked green to use a moment ago, and it will look gray in the morning [...] (transl. Brittain).

Scepticism, in: Regina Claussen; Roland Daube-Schackat (eds.): Gedankenzeichen. Festschrift für Klaus Oehler zum 60. Geburtstag, Tübingen 1988, 65-70; contrast Gail Fine: Sextus and External World Scepticism, in: Oxford Studies in Ancient Philosophy 23 (2003), 341-385. In saying that ancient sceptics are not external world sceptics, I intend to make a comment on the evidence we have. If a sceptic had found himself in a suitable dialectical situation, it is likely that he would have argued against the existence of a world external to our minds.

23 Cic. Luc. 105. It seems safe to exclude the possibility that in this passage the object - the sea - is itself meant to be taken as a mind-dependent component of the perceptual experience of the Academic sage at that moment, because of the communicative situation (the speaker invites the addressee to share focus). But it will be as well to note that the mere presence of deictic and other spatial expressions does not by itself establish the reference to the outside world (cf. also OLD s.v. uideo no. 3a: "[emphasizing the presence of the obj. of the vb.] To see; [also indicating the presence of the subj. in the locality of the obj.]"). When we read, of Hector's dream appearance to Aeneas, in Verg. Aen. 2,270-273: in somnis ecce ante oculos maestissimus Hector / uisus adesse mihi largosque effundere fletus, / raptatus bigis ut quondam aterque cruento / puluere perque pedes traiectus lora tumentis ("in slumbers, I dreamed that Hector, most sorrowful and shedding floods of tears, stood before my eyes, torn by the car, as once of old, and black with gory dust, his swollen feet pierced with thongs", transl. Fairclough/Goold), the phrase ante oculos should give us pause. It seems unsatisfactory to explain it with the rigid conventions of epic language, which supposedly allow for the paradoxical inclusion of ante oculos just because it is conventional, even in cases where there is nothing there to be seen ante oculos and any eyes are, one would think, closed. It seems preferable to think that ante oculos characterises the subjective feel of the dream appearance - it is as if Hector was before Aeneas' eyes. Contrast Verg. Aen. 2,772-773: infelix simulacrum atque ipsius umbra Creusae / uisa mihi ante oculos et nota maior imago ("there rose before my eyes the sad phantom and ghost of Creüsa herself, a form larger than her wont”, transl. Fairclough/Goold), where real seeing takes place and where there is something ante oculos, but it is a simulacrum. See also Marie-Dominique Joffre: Les conditions morphosyntaxiques de l'ambiguité volontaire l'emploi de videor dans les chants II et III de l'Énéide, in: Louis Basset; Frédérique Biville (eds.): Les jeux et les ruses de l'ambiguïté volontaire dans les textes grecs et latins. Actes de la table ronde organisée à la Faculté des Lettres de l'Université Lumière Lyon 2 (23-24 novembre 2000), Lyon 2005 (Collection de la Maison de l’Orient et de la Méditerranée 33), 91-99, at 9697. 
There are, however, two passages which need to be explained if we are to contend plausibly that Cicero's terminological choices in this area are the result of careful deliberation and acute analysis rather than the combined product of an insufficient understanding of the issues and hasty production. In these two passages Cicero introduces a Greek term ( $\kappa \alpha \tau \alpha \lambda \eta \pi \tau o ́ v)$, but gives an explanation of its reference which is at variance with the Greek record.

One of these is Lucullus 18, to be discussed below. The other is Academicus Primus 40-42, where Varro, in an account of the history of philosophy from Socrates to the Stoics, explains the modifications which Zeno made to the epistemology of the ueteres:

"Plurima autem in illa tertia philosophiae parte mutauit. in qua primum de sensibus ipsis quaedam dixit noua, quos iunctos esse censuit e quadam quasi impulsione oblata ex-

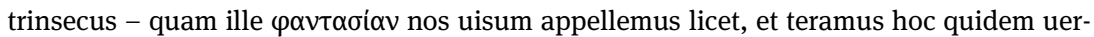
bum, erit enim utendum in reliquo sermone saepius - sed ad haec quae uisa sunt et quasi accepta sensibus assensionem adiungit animorum, quam esse uult in nobis positam et uoluntariam. (41) uisis non omnibus adiungebat fidem sed is solum quae propriam quandam haberent declarationem earum rerum quae uiderentur; id autem uisum cum ipsum per se cerneretur, comprehendibile - feretis haec?"

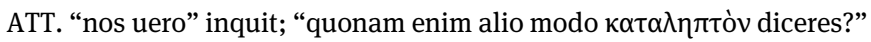

VA. "Sed cum acceptum iam et approbatum esset, comprehensionem appellabat, similem is rebus quae manu prenderentur; ex quo etiam nomen hoc duxerat [at] cum eo uerbo antea nemo tali in re usus esset, plurimisque idem nouis uerbis (noua enim dicebat) usus est. Quod autem erat sensu comprensum id ipsum sensum appellabat, et si ita erat comprensum ut conuelli ratione non posset scientiam, sin aliter inscientiam nominabat; ex qua existebat etiam opinio, quae esset imbecilla et cum falso incognitoque communis. (42) sed inter scientiam et inscientiam comprehensionem illam quam dixi collocabat, eamque neque in rectis neque in prauis numerabat, sed soli credendum esse dicebat. E quo sensibus etiam fidem tribuebat, quod ut supra dixi comprehensio facta sensibus et uera esse illi et fidelis uidebatur, non quod omnia quae essent in re comprehenderet, sed quia nihil quod cadere in eam posset relinqueret, quodque natura quasi normam scientiae et principium sui dedisset unde postea notiones rerum in animis imprimerentur; e quibus non principia solum sed latiores quaedam ad rationem inueniendam uiae reperiuntur. errorem autem et temeritatem et ignorantiam et opinationem et suspicionem et uno nomine omnia quae essent aliena firmae et constantis assensionis a uirtute sapientiaque remouebat.”

But he changed very many things in the third part of philosophy. There he first of all said something new about the senses themselves, which he regarded as conjoined from, on the one hand, a kind of impact on the mind from the outside - he called this phantasia, and we can may call it uisum, 'impression'; and let us hang on to this term, for there will be further occasions to use it in the rest of our conversation - but to the impressions which have, as it were, been picked up by the senses he added the assent of the mind, which he wants to reside with us and be subject to our will. (41) He did not extend credibility to all impressions but only to those which have a certain, peculiar way of revealing those things 
of which they are impressions; but such an impression, if you consider it just by itself, is apprehensible - do you think you understand?

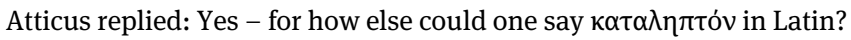

Varro: But once it has been accepted and approved, he called it 'apprehension', similar to those things which are grasped with a hand: from this he also drew the term because nobody had used this word previously of this subject, and in general he used very many new words (for what he was saying was new). But that which had been apprehended by sense perception, that he called sense perception itself, and if it was so firmly grasped that it could not be dislodged by argument, scientific knowledge, otherwise ignorance; from the latter stemmed also opinion, which he regarded as a weak state and shared with false and unknown impressions. (42) But between scientific knowledge and ignorance he placed apprehension (which I mentioned above), and apprehension counted neither among what is good nor among what is bad, and said it alone was deserving of our trust. It was because of the apprehension that he placed trust in the senses, because, as I said above, an apprehension which arose from the senses seemed to him to be true and reliable, not because it grasped everything that was in an object, but because it omitted nothing which could fall under it, and because nature had given apprehension as a standard for scientific knowledge and as a starting point. It was also the source from which later our conceptions would be stamped on the mind; from these not just the starting points but also the broader pathways towards the establishment of discursive knowledge are found. But error, rashness, ignorance, mere opining, supposition, and in a word everything that is alien to firm and solid assent he removed from virtue and wisdom.

What is in need of explanation in this passage, in general and also given what I have said above, is that Cicero says that an impression of the kind which he has just introduced (a cataleptic impression, sc. a mental item), considered by itself, i.e. before it has been assented to, is to be called comprehendibile, 'that which can be grasped'. ${ }^{24}$ In reply to the question if this was tolerable, Atticus asks how else one is supposed to render $\kappa \alpha \tau \alpha \lambda \eta \pi \tau$ óv. Cicero's translation of the Greek term is correct as far as the sense of the term is concerned, but he applies it to (cataleptic) impressions rather than objects in the world, and in a context where we would expect him to introduce impressions which are capable of grasping

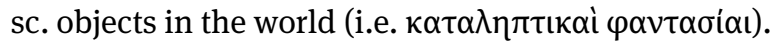

I had explained above that percipere uisum, where uisum is used for 'cataleptic impression', means 'to grasp an external object by means (or: in) an impression'. That this conception of what it means to have a cataleptic impression is in the background in our passage, too, is suggested by a rather inconspicuous

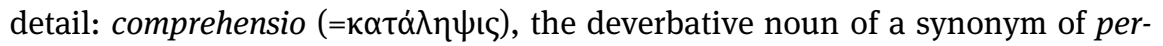

24 The context precludes the possibility that comprehendibilis is instrumental/active in meaning; see Manu Leumann: Lateinische Laut- und Formenlehre, Munich 1977 (Handbuch der Altertumswissenschaft 2,2,1), at 348-349 for this option in principle. 
cipere, is used in a passive sense ([41] comprehensionem appellabat, similem is rebus quae manu prenderentur), i.e. the mental item which is grasped, and in an active sense (comprehensio facta sensibus et uera esse illi et fidelis uidebatur, non quod omnia quae essent in re comprehenderet [...]), i.e. the mental item which grasps. ${ }^{25}$ (That in the latter case comprehenderet features in a nega-ted clause introducing a rejected reason seems unproblematic, since what is rejected is the notion that a comprehensio grasps all features of the object as opposed to salient ones.) The presence of the double perspective on grasping in our passage tells against a simple mistake on Cicero's part, because he does even here show awareness that the $\kappa \alpha \tau \alpha \lambda \dot{\eta} \psi \varepsilon \iota \varsigma$ resulting from cataleptic impressions are held to grasp objects.

Given that there was no confusion in Cicero's mind as to how the notion of grasping relates to impressions in Stoic thought, his use of $\kappa \alpha \tau \alpha \lambda \eta \pi \tau o ́ v$ with reference to an impression must have struck him as not problematic. Three possible reasons for this are the following. First, the terminological cluster centering on $\kappa \alpha \tau \alpha \lambda \alpha \mu \beta \alpha \dot{v \varepsilon ı v ~ b e c a m e, ~ a l r e a d y ~ i n ~ t h e ~ H e l l e n i s t i c ~ p e r i o d, ~ c o m m o n ~}$ currency in philosophical debate generally and was used in ways which represented a deviation from their original Stoic usage. The Cyrenaics held that the only thing we can be certain of are our bodily affections as opposed to representational states like impressions, and in the Greek sources this position is reported as the view that only these affections can be grasped; ${ }^{26}$ Cicero was familiar with the Cyrenaic position, as is clear from references to it in the Academica. ${ }^{27}$ Second, the debates about $\alpha \pi \alpha \rho \alpha \lambda \lambda \alpha \xi i \alpha$ mentioned above, which postdate the formulation of the definition of the cataleptic impression of course, at times created the need to claim that one was undergoing an impression A as opposed to an impression $\mathrm{B}$ which was exactly like it in every respect, ${ }^{28}$ and it seems conceivable that this was expressed in Greek as 'grasping an impression A',

25 This is recognised by the OLD s.v. compr(eh)ensio no. 5a and b, but not by the ThLL. The shift between grasping an object (of some sort) with the mind and grasping the mental item corresponding to an object is anticipated in the Rhetorica ad Herennium: contrast 2,30: res breuis est, ut facile memoria comprehendatur, and 3,20,33: rei [...] memoriam [...] una nota et imagine simplici comprehendimus. See Mario Puelma: Die Rezeption der Fachsprache griechischer Philosophie im Lateinischen, in: Freiburger Zeitschrift für Philosophie und Theologie 33 (1986), 45-69, at 55 n. 20.

26 See Voula Tsouna: The Epistemology of the Cyrenaic School, Cambridge 1998, 30-61, esp. $32 \mathrm{n} .2$.

27 E.g., Cic. Luc. 142.

28 See above, n. 11. Impressions can conceivably be different from one another qua alterations

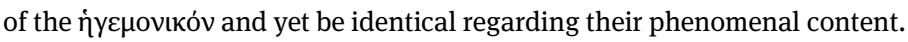


even if no such formulation is attested. Third, the Stoic view is that we have impressions which reveal themselves and their object, while we assent to impressions not objects represented by them. If one does not conceive of the possibility that there might be no world external to ourselves at all, as nobody in classical antiquity did (see above), then saying that one grasps an impression, used as a shorthand for grasping an object by means of an impression, would not sound like 'being certain about the content of one's perceptual beliefs qua subjective states only' as it does to the modern reader, conditioned as we are through brain-in-the-vat scenarios and the like. ${ }^{29}$

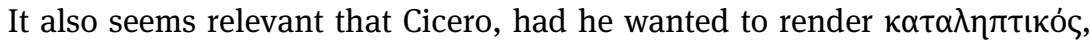
would have encountered various problems. One is the absence of an active verbal adjective meaning 'capable of $\varphi$-ing' in Latin. A uisum comprehendens would have meant an impression which actually grasps as opposed to being

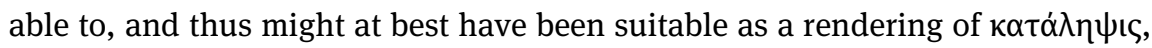
for which, as we saw, Cicero uses deverbative nomina actionis matching the Greek term morphologically. A phrasal term involving a clause, like uisum quod comprehendere potest, would have sat uncomfortably with the archetypal percipere uisum: the potential for misunderstanding that objects perceived can grasp would have been too great. Visum quod comprehendere potest would also have run into the problem that uisum had an established sense of 'apparition' before Cicero. ${ }^{30}$ So the ridiculous notion of ghosts being able to seize things would not have been far off, and we remember in this connection that Cicero himself made fun of the Epicurean Catius who rendered the term El$\delta \omega \lambda$ ov as spectra, which is the origin of English 'spectre' and is likely to have evoked the association with 'ghost' already in Cicero's time. ${ }^{31}$

In Augustine's works we find the notion that we can have secure knowledge only of three kinds of truths, such that nobody can confuse them through some

29 This also answers the question why Cicero used Greek terms at all if he knew his application of the term to impressions to be a deviant one: he did not take this view, as is also sugges-

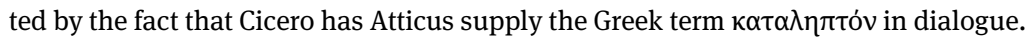

30 It is due to the accidents of survival that chronologically the earliest instances of uisum come from Cicero; cf. Verg. Aen. 4,450-456 (as in n. 18), which surely is not evidence for the early reception of the Academica.

31 See Cic. fam. 15,16,1-2 (with the reply by Cassius, 15,19,1): I am assuming that Cicero's point that it was unlikely that spectra were in our power (so that they can be summoned at will) combines substantial philosophical criticism with a joke (in meane potestate ut sit spectrum tuum, ut, simul ac mihi collibitum sit de te cogitare, illud occurrat?). See also Reinhardt: The Language of Epicureanism in Cicero, in: Tobias Reinhardt; Michael Lapidge; James Noel Adams (eds.): Aspects of the Language of Latin Prose, Oxford 2005, 151-177, at 156. 
similarity with what is false (Contra Academicos 3,10,23: nec similitudine aliqua falsi ea quisquam potest confundere): ${ }^{32}$ logical truths ('There is one world or there is not'), mathematical truths ('Three times three is nine'), and reports of immediate experience ('This tastes pleasant to me'). ${ }^{33}$ The similarity with the third clause of Zeno's definition of the cataleptic impression is not accidental. We also find traces of a notion that our cognitive reach is restricted to the mental, which was to prove an influential one in the history of philosophy down to the present day. Both notions can arguably be linked to Augustine's engagement with Cicero's Academica, and to Cicero's speaking of grasping uisa as opposed to grasping objects through or by means of impressions. In this section I want to look at the linguistic mechanics which enable this philosophical development, without suggesting that the latter can be reduced to the former.

As is well recognised, it is part of Augustine's wider philosophical agenda in Contra Academicos to reject Ciceronian scepticism so as to be able to claim that faith is a necessary condition for attaining knowledge. This explains Augustine's initially paradoxical engagement with Zeno's definition of the cataleptic impression: he characterises his three types of defensible knowledge claims in terms derived from Cicero's renderings of Zeno's definition, while rejecting the possibility of perceptual experience affording knowledge of states of affairs in the world.

The following three texts from Cicero, Augustine, and again Cicero illustrate how Augustine can do this:

(i) Cum enim ita negaret quicquam esse quod comprehendi posset (id enim uolumus esse

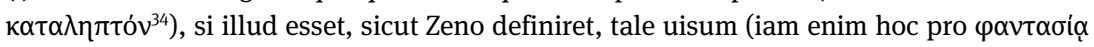

32 Similar passages are listed by Blake D. Dutton: Augustine, Academic Scepticism, and Zeno's Definition, in: Augustiniana 53 (2003), 7-30, at 24.

33 The three examples, taken from c. acad. 3,10,23-11,26, e.g. in Gareth B. Matthews: Knowledge and Illumination, in: Eleonore Stump; Norman Kretzmann (eds.): The Cambridge Companion to Augustine, Cambridge 2001, 171-184, at 172.

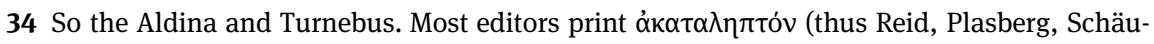
blin following the manuscripts, which are, however, a rough guide at best on Greek words), citing negaret as the reason why the negative Greek term was needed here. However, Cicero would have written something like diceret nihil esse quod comprehendi posset if an assertion made by Philo that everything was non-apprehensible was at issue here. This conclusion is only reached towards the end of the extract (nihil posse comprehendi), while Philo's intervention is presented as a rejoinder to Zeno's definition. The Greek term is clearly meant to correspond to quicquam esse quod comprehendi posset only. Independently, ac. 1,41 discussed above points to the same conclusion. Luc. 18, like ac. 1,41, gives the impression that it introduces the term. 
uerbum satis hesterno sermone triuimus) - (ii) uisum igitur impressum effictumque ex eo, unde esset, quale esse non posset, ex eo, unde non esset (id nos a Zenone definitum rectissime dicimus: qui enim potest quicquam comprehendi, ut plane confidas perceptum id cognitumque esse, quod est tale, quale uel falsum esset possit?) - hoc cum infirmat tollitque Philo, iudicium tollit incogniti et cogniti, ex quo efficitur nihil posse comprehendi. ${ }^{35}$

For when he denied that there was anything that could be grasped (this we want to be our rendering of $\kappa \alpha \tau \alpha \lambda \eta \pi \tau o ́ v)$, if this [illud referring back to quicquam [...] quod comprehendi posset] was, as Zeno defined, such an impression (for we had used this word - uisum - already for $\varphi \alpha v \tau \alpha \sigma i \alpha$ yesterday) - namely, an impression imprinted and moulded from that (object) from which it derived, of such a nature that it could not be as it is if it derived from an object from which it did not derive (we say that this definition of Zeno's is entirely correct: for how could anything be grasped, in such a way that you have complete confidence that it has been apprehended and cognised, which was of such a nature that it could also be false?) - by weakening and removing this proviso, Philo removes the ability to distinguish between what is cognised and what is not, which yields that nothing can be grasped.

Et omnia incerta esse non dicebant solum, uerum etiam copiosissimis rationibus affirmabant. (i) Sed uerum non posse comprehendi ex illa Stoici Zenonis definitione arripuisse uidebantur, qui ait id uerum percipi posse, (ii) quod ita esset animo impressum ex eo unde esset, ut esse non posset ex eo unde non esset. Quod breuius planiusque sic dicitur, his signis uerum posse comprehendi, quae signa non potest habere quod falsum est. Hoc prorsus non posse inueniri, uehementissime ut conuincerent incubuerunt. Inde dissensiones philosophorum, inde sensuum fallaciae, inde somnia furoresque, inde pseudomeni et soritae in illius causae patrocinio uiguerunt. Et cum ab eodem Zenone accepissent, nihil esse turpius quam opinari, confecerunt callidissime, ut si nihil percipi posset, et esset opinatio turpissima, nihil umquam sapiens approbaret. ${ }^{36}$

And that everything is uncertain they not just asserted, but also supported with numerous arguments. But that the true could not be grasped they seemed to obtain from that definition of the Stoic Zeno, who said that true item could be apprehended ${ }^{37}$ which was imprintted on the mind by that from which it derived in such a way that it could not have arisen from that from which it did not derive. This can be said more crisply and plainly in the following way: that the true can be grasped due to those marks which that which is false cannot have. And that could not be found, as they were at great pains to convince everyone of. Accordingly, in support of this cause of theirs they stressed the disagreements of philosophers, the errors of the senses, dreams and perturbed mental states, and fallacies and sophisms. And because they accepted the claim of the same Zeno that nothing was more objectionable than opining, they brought it about very cleverly that, if nothing can

35 Cic. Luc. 18.

36 Aug. c. acad. 2,5,11.

37 See below on the question of whether uerum is an attribute or a complement. 
be grasped and if opining was most objectionable, then the sage would never assent to anything.

(Arcesilaus) quaesiuit de Zenone fortasse quid futurum esset si nec percipere quicquam posset sapiens nec opinari sapientis esset. ille, credo, nihil opinaturum, quoniam esset, quod percipi posset. quid ergo id esset. 'uisum', credo. 'quale igitur uisum?' tum illum ita definisse: ex eo quod esset sicut esset impressum et signatum et effictum. post requisitum etiamne si eius modi esset uisum uerum quale uel falsum. hic Zenonem uidisse acute nullum esse uisum quod percipi posset, si id tale esset ab eo quod est cuius modi ab eo quod non est posset esse. recte consensit Arcesilas ad definitionem additum, neque enim falsum percipi posse neque uerum si esset tale quale uel falsum; incubuit autem in eas disputationes ut doceret nullum tale esse uisum a uero ut non eiusdem modi etiam a falso possit esse. ${ }^{38}$

Arcesilaus asked Zeno, as we may assume, what would happen if the sage was not able to grasp anything and if the sage was not supposed to opine. Zeno, I suppose, replied that the sage would not opine, because there was something which could be grasped. 'Namely?' asked Zeno. 'An impression' was, I believe, the answer. 'And what kind of impression?' Then Zeno defined it as follows: an impression which was imprinted, stamped, and moulded from that which is, in such a way as it is. The next question turned on whether this was so, too, in a case where the true impression was such that it could also be false. Here Zeno saw clearly that there could be no impression which can be grasped if it derives from what is in such a way that it could also derive from that which is not. Arcesilaus agreed that it was right (for Zeno) to make an addition to the definition, for neither what is false nor what is true could be securely grasped if the latter was of such a quality as the former, but he devoted particular effort to these debates in order to show that there was no impression from something true which could not have the same quality and derive from something false.

Contra Academicos 2,5,11 is the first passage in that work where Zeno's definition occurs. It cannot be ruled out that Augustine used the second edition of the Academica as a point of reference here, but if he did, the substantial similarities between Lucullus 18 and Contra Academicos 2,5,11, down to the grammatical lay-out of the sentences introducing the definition (highlighted through small Roman numerals above), suggest that, as far as this passage is concerned, there was very little recasting between Cicero's first and second edition.

Fuhrer has shown that the apparent shift from uisum to uerum in Lucullus 18 and Contra Academicos 2,5,11, respectively, ${ }^{39}$ requires an explanation, and has

38 Cic. Luc. 77.

39 See Therese Fuhrer: Das Kriterium der Wahrheit in Augustins ,Contra Academicos', in: Vigiliae Christianae 46 (1992), 257-275, at 257-265; Fuhrer: Augustin, Contra Academicos (vel De Academicis), Bücher 2 und 3, Berlin/New York 1997 (Patristische Texte und Studien 46), 151-153. 
suspected Augustine of advancing his own agenda by manipulating the Ciceronian model and replacing one term with the other. Augustine does indeed advance his own agenda here (which is to obtain from Zeno's definition as formulated by Cicero the insight that only truths can be grasped, and to interpret - in a second step - these truths as something other than perceptual representations of the external world), but he does it not by a sleight of hand, but by an acute reading of Cicero's text. ${ }^{40}$ As I noted above, the correct interpretation of Zeno's definition must be that veridicality is established through the first not the second clause. Cicero does rather elegantly capture this point in Lucullus 77 (ex eo quod esset sicut esset), the second passage in Lucullus where he talks about Zeno's definition at some length, while he fails to translate the first clause of Zeno's definition in Lucullus 18 in such a way that it establishes the truth of the impression as opposed to its causal origin in an actually existing object, as already Reid noted..$^{41}$ What Augustine does, then, is correct or at least clarify what Cicero says in Lucullus 18 through reference to Lucullus 77. (That Contra Academicos 2,5,11 draws on more than one Ciceronian passage is also clear from the reference to signa immediately following, on which see below.) If according to Lucullus 77 a cataleptic impression is a true impression (sc. true in virtue of the fact that it derives from an actually obtaining state of affairs, obtaining in virtue of a predicate being true of an object) which meets further conditions, then it is no misrepresentation to say (in Contra Academicos 2,5,11) that according to Zeno we grasp the truth by grasping a particular truth which meets further conditions, bearing in mind that impressions and what exactly they are have at this point not yet featured in Contra Academicos.

Fuhrer renders uerum or id uerum in Contra Academicos 2,5,11 as 'true object' ('wahres Objekt'). ${ }^{42}$ This would seem to amount to two different claims about this passage: that id or id uerum ${ }^{43}$ refers to the object of perception (i.e. to

40 While we have no reason to believe that Augustine had any access to the Greek background or would have been able to make use of it, we have every reason to think that he was a highly sophisticated reader of Cicero, well able to make the kind of intra-textual connection which I am about to posit.

41 James S. Reid: M. Tulli Ciceronis Academica, London 1885, 195.

42 Fuhrer: Augustin (as in n. 39), 151; Fuhrer: Kriterium (as in n. 39), 264.

43 Fuhrer considers the possibility that uerum in id uerum is a complement not an attribute. The context makes it clear that regarding something as 'true' which may be 'false' (however either term is interpreted) is not at issue, and since id uerum percipere cannot be interpreted as object, complement, and verb with percipere being factive (so as to mean 'to grasp that which is true as true'), uerum must be an attribute. (On factive verbs see Paul Kiparsky; Carol Kiparsky: Fact, in: Manfred Bierwisch; Karl Erich Heidolph [eds.]: Progress in Linguistics. A 
an external object), and that uerum means 'actually underlying' ('tatsächlich zugrundeliegend'), of a particular object. ${ }^{44}$ However, other details of the passage preclude the possibility that id (uerum) refers to an object perceived and that uerum means 'actually underlying' here. The way in which the sentence continues makes it clear that a truth imprinted on the mind by the object (animo impressum ex eo unde esset) is at issue, which forces the reader to interpret the truth in question as a mental item even in the absence of the term uisum, which Augustine only introduces later. (We must remember here that the readership presupposed by Contra Academicos was in all likelihood not expected to make sense of Augustine's text by reading it against Cicero's Academica.) That truths are said to be marked out by signa points in the same direction, since in the Academica Cicero speaks of the signs of cataleptic impressions as marks of their catalepticity (e.g. Lucullus 111: signum, 110: nota).

My interpretation, which assumes no shift between object perceived and experience had within 2,5,11, also makes it easier to understand how Augustine can later switch from uerum percipere to expressions like ueritatem percipere (e.g. Contra Academicos 2,6,14; 2,9,22; 3,3,5) in relevantly similar contexts, which would otherwise be a dubious move. ${ }^{45}$

Contra Academicos 3,9,21 offers a proof that the conditions set by the Zenonian definition can be met; I quote the beginning of the section:

Tamen quod Zeno definiuit, quantum stulti possumus, discutiamus. Id uisum ait posse comprehendi, quod sic appareret, ut falsum apparere non posset. Manifestum est nihil aliud in perceptionem uenire. Hoc et ego, inquit Archesilas, uideo, et hoc ipso doceo nihil percipi. Non enim tale aliquid inueniri potest. Fortasse abs te atque ab aliis stultis; at a sapiente cur non potest? Quamquam et ipsi stulto nihil responderi posse arbitror, si tibi dicat ut illo memorabili acumine tuo hanc ipsam Zenonis definitionem refellas, et ostendas eam etiam falsam esse posse; (A) quod si non potueris, hanc ipsam quam percipias habes, (B) si autem refelleris, unde a percipiendo impediaris non habes. Ego eam refelli posse non uideo et omnino uerissimam iudico. Itaque cum eam scio, quamuis sim stultus, nonnihil scio.

collection of papers, The Hague/Paris 1970 [Ianua linguarum, Series maior 43], 143-173; on factive attitudes see Timothy Williamson: Knowledge and Its Limits, Oxford 2000, at 5-8 and 21-38.) This is in line with the Ciceronian use of percipere, which is itself modelled on $\kappa \alpha \tau \alpha \lambda \alpha \mu \beta \alpha \dot{v \varepsilon \varepsilon v}$ in this respect (but note the deviant use in Cic. Luc. 77: neque enim falsum percipi posse neque uerum si esset tale quale uel falsum; contrast, e.g., Luc. 83: e quibus primum est, esse aliquod falsum uisum; secundum, non posse id percipi).

44 Fuhrer: Augustin (as in n. 39), at 151 cites Cic. Luc. 77 and 112, passages where to my mind uerum renders tò u̇ंápxov in the sense explained above.

45 For these passages see Fuhrer: Kriterium (as in n. 39), 265. 
But let us discuss what Zeno has defined, as far as stupid people like us are able to. He said that uisum can be grasped which appears in such a way as a falsehood cannot appear. It is clear that nothing else enters into perception. 'That I see, too', said Arcesilaus, 'and for that reason I teach that nothing can be perceived. For no such thing can be found.' Maybe not by you and by other stupid people, but why can a sage not find it? I for one think that nothing can be said in reply to a stupid person if he tells you that you, with your famous acumen, should refute that very definition of Zeno's, and should show that it, too, can be false. (A) If you can't do this, you will have one thing that you do perceive the definition itself, (B) but if you do refute it, you have nothing that would prevent you from perceiving. I do not see that it can be refuted and regard it as wholly true. Therefore, when I do know that definition, even though I am stupid, I know something.

Two passages after 2,5,11 resume the Zenonian definition in some detail, 3,9,18 and 3,9,21. Both feature uisum in the position where 2,5,11 had uerum. In order to read 3,9,21 coherently with 2,5,11, we need to assume that uisum here means 'that which has appeared truly' as opposed to 'that which has appeared (whether truly or not)' - Augustine takes Zeno to claim that humans can grasp true items of a certain kind (namely necessarily true items). Vt falsum apparere non posset means '(in such a way) as the false cannot appear', not '(in such a way) that the uisum cannot appear false', i.e. sic [...] ut must mean 'in such a way as', and falsum must be the grammatical subject of the clause in which it features. This is suggested by 3,9,18, where the formulation is: tale scilicet uisum comprehendi et percipi posse, quale cum falso non haberet signa communia. In this sentence tale [...] quale favours reading sic [...] ut in 3,9,21 as 'in such a way as', and the uisum is said to share, as a matter of fact, no mark with the false, as opposed to not appearing false. Appearance of truth would be a property which true and (some) false uisa share; Augustine is concerned with the kind of appearance only true uisa can have. A similar argument could be made from 2,5,11.

In the rest of the extract, the definition is then argued for and taken to be one instance of something one can know (itaque cum eam scio, quamuis sim stultus, nonnihil scio), i.e. one instance of a uisum that one can grasp. In this paragraph uisum has completed its journey to the sense 'that which has appeared truly' as an unambiguously subjective state, as opposed to the Ciceronian instances of uisum as a referential mental state qua mental state. A little later $(3,11,26)$ Augustine will expand on knowledge of subjective states in virtue of the fact that they are subjective states.

And when in 3,11,24 Augustine comes to designate the whole of our subjective experience as 'quasi-world' (quasi terra) which we can 'see' even while asleep (3,11,25: Etiamne, inquies, si dormis, mundus est iste quem uides? Iam dictum est, quidquid tale mihi uidetur, mundum appello), then we can contrast this with Lucullus 105 above, where the deictic pronoun in mare illud is an invi- 
tation by the speaker, extended to the listeners, to consider something in the external world, about whose colour we cannot be certain, but whose existence we naturally assume.

Cicero's talking about the grasping of uisa as opposed to objects enabled the emergence of Augustine's quasi-world in which sceptical (and other) scenarios continue to be played out in contemporary epistemology and philosophy of mind. 
Bereitgestellt von | De Gruyter / TCS

Angemeldet

Heruntergeladen am | 18.12.17 12:01 